\title{
PROBLEMATIKA PEMBELAJARAN KITĀBAH DAN TARJAMAH DI MADRASAH IBTIDAIYAH
}

Nanik Setyowati ${ }^{1}$,Hermin Setya Indrawati SY. ${ }^{2}$

1 Institut Agama Islam Sunan Giri (INSURI) Ponorogo; isnasetyo100585@gmail.com

${ }^{2}$ Institut Agama Islam Sunan Giri (INSURI) Ponorogo

\section{ARTICLE INFO}

Keywords;

Problems, Writing, Translating, Arabic

\section{A B S T R A C T}

The Arabic language is one of the competencies that must be mastered by the elementary school (Madrasah Ibtidaiyah/MI) students. However, in the course of learning Arabic, there are still various learning problems, especially in writing and translating Arabic. Speaking about the problem of learning Arabic, which was the object of research, the writers hoped to solve that problem or at least could reduce the gap. This study aimed to describe the learning patterns of writing skills and the ability to translate Arabic in Ml, problems and find the right solution to support the learning of writing skills and the ability to translate Arabic in $\mathrm{Ml}$ involving all components in the school, namely teaching materials, teachers, the principal's learning and policy process. This research is a qualitative study using descriptive-qualitative methods. The data used include two things, namely primary data and secondary data. Data collection technique was in the form of documentation. The researchers were trying to collect data relevant to learning Arabic in Ml systematically, which were then analyzed by theory. The data analysis technique used grounded research in which the researchers analyzed the data and existing problems with the theory used. This research takes focus on the students of Class V Madrasah Ibtidaiyah AlJihad Karanggebang Jetis Ponorogo. Based on the data analysis, it was concluded that learning to write and translate Arabic in MI had been going well. However, there were still problems including lack of student interest, students' negative assumptions about Arabic, and students who were still at the level of reading (iqra'). Teachers' efforts in overcoming these problems included familiarizing students with the Arabic vocabulary (mufradat) used in learning materials through the translating method and extra activities in the form of Foreign Language Development Programs.

\section{PENDAHULUAN}

Bahasa merupakan alat komunikasi bagi manusia dalam berinteraksi sehari-hari antara satu individu dengan yang lain, dalam bermasyarakat atau berdiplomasi dengan negara 




APHORISME

Journal of Arabic Language, Literature, and Education

Vol. 1, No.1(2020)

Aphorisme@insuriponorogo.ac.id

Homepage:https://ejournal.insuriponorogo.ac.id/index.php/Aphorisme

lain. Dalam kegiatan sekecil apapun di masyarakat, bahasa diperlukan untuk memperlancar proses komunikasi. Oleh karena itu, pengajaran bahasa sangat diperlukan agar masyarakat dapat menggunakan bahasa dengan baik dan benar sehingga komunikasi dapat berjalan dengan lancar.

Bahasa Arab kini memiliki kedudukan yang sangat istimewa, bukan hanya sebagai bahasa Al-Qur'an dan bahasa umat Islam, namun juga sebagai bahasa Internasional. Keberadaannya kini sudah tidak diragukan lagi. Pada saat ini bahasa Arab sudah mulai digunakan sebagai bahasa sehari-hari dan juga sebagai bahasa pergaulan anak-anak pada zaman sekarang. Bahasa Arab memiliki karakteristik yang sangat istimewa selain bahasa Al-Qur'an terutama dilihat dari struktur tatanannya. Bahasa Arab juga merupakan bahasa yang indah namun sangat berbeda dari bahasa lain sehingga itu diperlukan kejelian dalam memahaminya.

Kendati demikian, yang sangat disayangkan adalah akhir-akhir ini bahasa Arab bukan lagi pelajaran yang diminati oleh peserta didik baik di sekolah formal, informal maupun non formal, namun bahasa Arab cenderung menjadi pelajaran yang menakutkan untuk dipalajari dan digemari (Zulhannan, 2014). Kondisi ini masih perlu dieksplorasi secara mendalam tentang sebab ketidaktertarikan peserta didik, apakah disebabkan karena metode yang digunakan guru kurang menarik dan variatif atau karena disebabkan oleh faktor-faktor lain yang menghilangkan gairah peserta didik untuk mempelajari bahasa Arab.

Berangkat dari problematika tersebut, saat ini banyak siswa yang merasa takut dengan mata pelajaran bahasa Arab, padahal mereka belum mempelajarinya. Ketika siswa mendengar nama mata pelajarannya pasti sudah enggan mengenal, apalagi untuk mendalaminya. Mereka berpikir bahwa mata pelajaran tersebut merupakan momok terbesar dalam hidupnya. Di sinilah peran guru dibutuhkan dalam proses pembelajaran dibuat semenarik mungkin untuk membuat siswa bisa menyukai terlebih dahulu baru mereka bisa dan termotivasi untuk mau belajar.

Dalam pembelajaran Bahasa Arab, seorang guru diharapkan dapat membaca cerminan visualisasi kondisi mental siswa yang hendak belajar bahasa asing (Arab) dan membayangkan asosiasi pikiran mereka. Untuk lebih menarik para siswa dan agar aktivitas pembelajaran menjadi lebih hidup, perlu adanya media, pembelajaran yang 


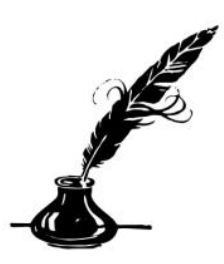

APHORISME

Journal of Arabic Language, Literature, and Education

Vol. 1, No.1 (2020)

Aphorisme@insuriponorogo.ac.id

Homepage:https://ejournal.insuriponorogo.ac.id/index.php/Aphorisme

mengutamakan praktek lisan dan latihan-latihan percakapan, latihan menulis, membaca buku-buku, dan dilanjutkan dengan praktik mengarang.

Proses pembelajaran juga dapat diartikan sebagai suatu rangkaian interaksi antara siswa dan guru dalam rangka mencapai tujuannya (Syamsuddin, 2005), yaitu tujuan memperoleh pengetahuan dari proses pembelajaran tersebut. Dengan kata lain, pengertian pembelajaran adalah proses untuk membantu peserta didik agar dapat belajar dengan baik. Pembelajaran adalah upaya untuk belajar. Kegiatan ini akan mengakibatkan siswa mempelajari sesuatu dengan cara efektif dan efisien (Muhaimin, 1996). Sebagian hal yang disebutkan oleh Nababan bahwasannya arti pembelajaran adalah nominalisasi proses untuk membelajarkan (Jos D Parera, 1997).

Dalam pembelajaran sebagai pendukung memang dibutuhkan media, namun tetap saja yang paling mempengaruhi adalah guru dalam mata pelajaran tersebut, khususnya bahasa Arab. Tugas guru ialah memintarkan juga memberikan materi sampai siswa bisa paham, karena setiap proses pembelajaran sangat dibutuhkan kepekaan seorang guru terhadap para siswanya bukan hanya memberikan materi. Dalam hal ini, guru dianggap anak panah atau momok yang selalu siap menerjang, karena siswa cenderung untuk tidak mau bertemu karena menganggap bahasa Arab sebagai kesulitan. Siswa cenderung menganggap belajar bahasa Arab merupakan suatu beban yang entah mereka pikir tidak bermanfaat. Bila siswa berbuat salah ketika menggunakan bahasa asing (Arab), guru cenderung pesimis. Akibatnya, pembelajaran bahasa dianggap suatu beban. Biasanya, seorang yang diberi beban cenderung untuk mau menerimanya sedikit mungkin bahkan kalau perlu dibuang (dilupakan) karena ia ingin menghindari kesulitan. Hal itu pula yang terjadi pada siswa yang membuatnya menghindari pelajaran bahasa asing (Arab).

Dalam pembelajaran bahasa Arab, masih ada kesulitan yang dihadapi oleh siswa, antara lain penerjemahan bahasa Arab, dan penulisan. Sejauh ini pembelajaran bahasa Arab masih bisa berjalan, meski siswa masih kesulitan. Guru harus selalu berusaha memberikan materi dengan metode yang mudah seperti qiroah dan diselingi yang lain. Namun dalam pembelajaran bahasa Arab, keterampilan menulis masih menjadi kesulitan siswa, terutama dari latar belakang yang masih di jilid lqra, karena mereka belum belajar huruf yang bersambung. Demikian juga kesulitan dalam penerjemahan juga masih menjadi momok siswa. 


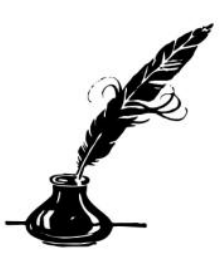

APHORISME

Journal of Arabic Language, Literature, and Education

Vol. 1, No.1(2020)

Aphorisme@insuriponorogo.ac.id

Homepage:https://ejournal.insuriponorogo.ac.id/index.php/Aphorisme

Menulis merupakan kemampuan menggunakan pola-pola bahasa secara tertulis untuk mengungkapkan suatu gagasan (Rusyana, 1988). Menulis pada hakikatnya adalah upaya mengekspresikan apa yang dilihat, dialami, dipikirkan dan dibaca ke dalam bahasa tulisan. Tradisi menulis ini dapat diartikan sebagai suatu kebiasaan untuk menyatakan gagasan atau pendapat secara tertulis. Penguasaan bahasa tulis mutlak diperlukan dalam kehidupan modern sekarang ini. Setiap orang pernah melakukan aktifitas menulis. Namun demikian, ternyata banyak orang yang kekurangan ide atau bisa jadi idenya banyak tetapi tetap saja kesulitan dalam menulis. Dunia informasi telah berkembang demikian pesat, dengan pesatnya perkembangan dunia informasi khususnya perkembangan kegiatan tulis menulis, tentu menuntut kita agar mengembangkan tradisi menulis.

Keterampilan menulis (mahārah al-kitābah/writing skill) adalah kemampuan dalam mendeskripsikan atau mengungkapkan isi pikiran, mulai dari aspek yang sederhana seperti menulis kata-kata sampai kepada aspek yang kompleks yaitu mengarang (Hermawan, 2011). Keterampilan menulis dalam pelajaran bahasa Arab secara garis besar dapat dibagi ke dalam tiga kategori yang tak terpisahkan, yaitu imlä (al-imlā'), kaligrafi (al-khath), dan mengarang (al-insyā').

Menerjemahkan dalam Kamus Besar Bahasa Indonesia berarti menyalin atau memindahkan dari suatu bahasa ke bahasa lain. Kata terjemah sendiri berasal dari bahasa Arab, yakni “tarjamatun" yang mengandung arti menjelaskan dengan bahasa lain atau memindahkan makna dari satu bahasa ke dalam bahasa lain (Al Farisi, 2011). Dalam hal ini yang dimaksud adalah mengalihkan bahasa Arab ke dalam bahasa Indonesia, sehingga bisa dipahami oleh orang lain atau pembaca.

Metode gramatika-terjemahan (Tarīqah al-Qawā'id wa al-Tarjamah) berasal dari dua metode, yaitu metode qawa''id dan metode terjemahan. Metode qawā'id adalah metode yang menekankan pada penghafalan aturan-aturan gramatika atau rules of grammar dan sejumlah kata-kata tertentu (Ahmad Fuad, 2009). Metode terjemah adalah metode yang menitikberatkan pada kegiatan-kegiatan menerjemahkan bacaan-bacaan. Mula-mula dari bahasa asing ke dalam bahasa siswa, kemudian sebaliknya, yaitu dari bahasa Arab ke dalam bahasa Indonesia, atau bahasa Indonesia ke dalam bahasa Arab. 


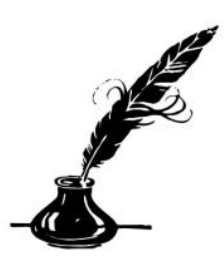

APHORISME

Journal of Arabic Language, Literature, and Education

Vol. 1, No. 1(2020)

Aphorisme@insuriponorogo.ac.id

Homepage:https://ejournal.insuriponorogo.ac.id/index.php/Aphorisme

Ketika membaca sebuah teks, sesungguhnya kita sedang melakukan penerjemahan. Berkaitan dengan hal ini misalnya, Gadamer (dalam Schulte dan Biguenett, 1992) mengungkapkan bahwa reading is alredy translation and translation is translation for the second time yang artinya membaca sudah merupakan penerjemahan dan penerjemahan adalah penerjemahan untuk kedua kalinya (Ahmad Fuad, 2009).

Kesulitan dalam belajar bahasa Arab ini juga terjadi di Madrasah Ibtidaiyah. Madrasah Ibtidaiyah merupakan jenjang pertama kali siswa mengenal pelajaran bahasa Arab dengan berbagai latar belakang kemampuan setiap siswa yang berbeda-beda. Perbedaaan input siswa di MI inilah yang menjadi latar belakang problem yang dihadapi siswa. Sebagaimana kondisi pembelajaran yang peneliti amati di Madrasah Ibtidaiyah AlJihad Karanggebang Kecamatan Jetis Kabupaten Ponorogo. Dari hasil penilaian keterampilan menulis dan menerjemah bahasa Arab masih sangat kurang. Hal ini juga dapat dilihat dari nilai hasil praktikum menulis (kitābah) dan kemampuan siswa dalam menerjemahkan arti kata dari bahasa Arab yang mereka pelajari.

Problem yang menjadi momok siswa itu mengarah pada keterampilan menulis aksara Arab dan menerjemahkaan bahasa Arab ke bahasa Indonesia. Ketika pembelajaran, guru sudah memberikan penjelasan dan terkadang diselingi dengan nyanyian agar lebih mudah dipahami siswa, namun tetap saja ketika diberi latihan soal, baik menulis maupun menerjemah, siswa masih belum tahu arti dari mufradat-nya.

Dari studi pendahuluan yang dilakukan tersebut, peneliti menemukan banyak problem yang dihadapi siswa di antaranya; siswa mengalami kesulitan menulis bahasa Arab; siswa masih kesulitan menerjemah bahasa Arab ke dalam bahasa Indonesia. Problem pembelajaran bahasa Arab di MI Al Jihad dimulai dari kesulitan menulis dan menerjemah. Hal tersebut membutuhkan upaya yang dilakukan guru untuk mengatasi berbagai problem tersebut dari problematika di atas, penulis lebih tertarik untuk mengambil penelitian di kelas lima Madrasah Ibtidaiyah Al-Jihad Karanggebang Kecamatan Jetis Kabupaten Ponorogo. Guna mengetahui upaya mengurangi kesenjangannya, maka perlu diketahui sebabnya terlebih dahulu dari yang paling dasar. Dalam hal ini, kelayakan suatu masalah untuk diteliti sangat bersifat relatif, sebab kelayakan akan tergantung pada konteks permasalahan. 


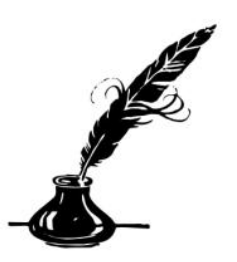

APHORISME

Journal of Arabic Language, Literature, and Education

Vol. 1, No.1(2020)

Aphorisme@insuriponorogo.ac.id

Homepage:https://ejournal.insuriponorogo.ac.id/index.php/Aphorisme

Peneliti menegaskan mengenai signifikasi penelitian ini, yakni membahas problematika pembelajaran bahasa Arab. Dengan demikikian, problematika pembelajaran menulis (kitābah) dan menerjemah bahasa Arab sebagai fokus penelitian ini. Peneliti berharap dapat memecahkan masalah itu atau setidaknya peneliti dapat memperkecil kesenjangannya.

\section{METODE}

Penelitian ini merupakan penelitian kualitatif dengan pendekatan deskriptif, yaitu prosedur penelitian yang menghasilkan data deskriptif berupa kata-kata tertulis, lisan dari orang-orang dan perilaku yang diamati, penyusunan dan pengumpulan data, kemudian dianalisa dan diinterprestasi tentang data yang diperoleh (Sugiyono, 2008). Data berupa kata-kata dan fakta di lapangan tempat peristiwa secara natural (alami) yaitu data yeng terkait dengan proses pembelajaran keterampilan menulis dan menerjemah bahasa arab dan data tentang upaya yang dilakukan guru untuk mengatasi problematika tersebut. Data dikumpulkan dari orang yang terlibat dalam tingkah laku alamiah seperti guru, siswa dan lain-lain dengan teknik wawancara, observasi dan dokumentasi. Analisis data penelitian ini menggunakan model Miles dan Huberman melalui 3 tahap yaitu reduksi data, penyajian data, dan penarikan kesimpulan.

\section{PEMBAHASAN}

\section{PEMBELAJARAN BAHASA ARAB DI MI AL-JIHAD KARANGGEBANG JETIS PONOROGO}

Sesuai Permenag RI nomor 02 tahun 2008, mata pelajaran bahasa Arab di Madrasah Ibtidaiyah sudah mulai diajarkan kepada siswa sejak kelas IV-VI. Dalam Standar Kompetensi (SK) pembelajaran bahasa Arab di Madrasah Ibtidaiyah sudah terpetakan menjadi empat SK yaitu; kemampuan mendengar, berbicara, membaca, dan menulis. Hanya saja realitasnya, dari keempat kemampuan tersebut yang paling dominan hanya kemampuan pasif (membaca dan menulis) dari pada kemampuan aktif (mendengar dan berbicara) (Taufiq, 2016). Sesuai dengan peraturan tersebut, MI Al Jihad Karanggebang Jetis Ponorogo memberlakukan pelajaran bahasa Arab dimulai pada jenjang kelas IV.

Sebagaimana hasil observasi dan dokumentasi di lokasi penelitian, Ml Al-Jihad Karanggebang, bahwa jadwal mata pelajaran Bahasa Arab dilaksanakan seminggu sekali 


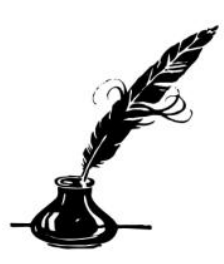

APHORISME

Journal of Arabic Language, Literature, and Education

Vol. 1, No.1(2020)

Aphorisme@insuriponorogo.ac.id

Homepage:https://ejournal.insuriponorogo.ac.id/index.php/Aphorisme

yakni 2 jam pelajaran tiap minggunya. Dengan diampu oleh Guru yang berlatar belakang pendidikan Pondok Pesantren dan Perguruan Tinggi Negeri Jurusan Pendidikan Bahasa Arab bernama Nurul Hidayati, S.Pd.I. Beliau dinilai sudah berpengalaman di dalam mengajar Bahasa Arab sehingga dipercaya untuk mengajar Bahasa Arab di Ml Al-Jihad Karanggebang. Dengan singkatnya pertemuan tersebut, maka intensitas pembelajaran bahasa Arab bagi siswa dirasa masih kurang mencukupi, sehingga kemampuan menulis dan menerjemahkan bahasa Arab siswa kurang terasah.

Dalam pembelajaran bahasa arab di MI Al Jihad Karanggebang Jetis Ponorogo menekankan pada penguasaan 4 keterampilan pokok bahasa, salah satunya adalah menulis. Keterampilan menulis dalam pelajaran bahasa Arab secara garis besar dibagi ke dalam tiga kategori yang tak terpisahkan, yaitu imla' (al imla'), kaligrafi (al khath), dan mengarang (al insya') (Hermawan, 2011). Pembelajaran menulis bahasa arab dapat dilihat dari 4 aspek; yaitu menulis menggunakan huruf Arab, menulis kalimat dengan huruf hijaiyyah yang sempurna, membuat susunan kalimat yang dapat difahami oleh pembaca, menggunakan susunan kalimat dalam jumlah bahasa arab dari setiap paragraf dengan ungkapan tulisan yang jelas. Dalam hal ini peneliti fokuskan pada kemampuan menulis imla', yaitu mengamati proses pembelajaran menulis kosa kata (Mufradat) menggunakan huruf hijaiyyah dengan baik dan benar.

Penguasaan kemampuan berbahasa secara aktif sebenarnya merupakan tuntutan dasar bagi pembelajar bahasa. Karena indikator pengukuran keberhasilan siswa dalam berbahasa arab adalah kemampuan berbicara itu sendiri. Namun demikian permasalahan yang sering muncul adalah lemahnya kemampuan berbahasa pasif (menulis dan menerjemah), apalagi untuk memenuhi tuntutan berbahasa aktif menjadi problem tersendiri bagi pendidik bahasa arab di MI (Taufiq, 2016).

Untuk pembelajaran menulis dan menerjemah di MI Al Jihad Karanggebang Jetis Ponorogo menggunakan buku pegangan terbitan ERLANGGA dan Lembar Kerja Siswa (LKS) Bahasa Arab sebagai pendukungnya. Tujuannya agar siswa lebih mudah dalam belajar dan mempermudah proses belajar mengajar di Ml Al-Jihad ini terutama penguasaan ketrampilan menulis dan menerjemah.

Metode pembelajaran bahasa Arab sangat variatif. Para pakar profesional pembelajaran bahasa Arab telah melakukan perdebatan panjang terkait hal tersebut. 


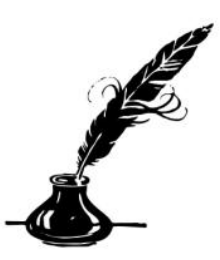

APHORISME

Journal of Arabic Language, Literature, and Education

Vol. 1, No. 1(2020)

Aphorisme@insuriponorogo.ac.id

Homepage:https://ejournal.insuriponorogo.ac.id/index.php/Aphorisme

Hasilnya adalah bahwa masing-masing metode mampunyai kekuatan dan kelemahan, sehingga muncul statement "tidak ada satu metode apapun yang dianggap paling ideal untuk diterapkan dalam sebuah proses pembalajaran bahasa Arab (Muhammad Ali, 1986). Metode yang digunakan dalam kegiatan belajar mengajar Bahasa Arab di MI AlJihad Karanggebang ini adalah metode ceramah dan dikte. Guru mengaku mengalami kesulitan untuk menerapkan macam-macam metode pembelajaran Bahasa Arab karena sebagian siswa belum bisa berbahasa Arab dengan baik dan benar (Nurul Hidayati, 2019).

Kedua metode tersebut dianggap kurang menarik sehingga perlu adanya variasi metode pembelajaran. Namun di samping itu, Guru juga mengaku mengalami kesulitan untuk menerapkan macam-macam metode pembelajaran Bahasa Arab dikarenakan sebagian siswa belum bisa berbahasa Arab dengan baik dan benar. Selain itu metode ceramah dan dikte tidak sesuai dengan pembelajaran menulis dan menerjemahkan bahasa Arab. Pembelajaran menulis dan menerjemahkan merupakan pembelajaran dengan sasaran kemampuan berbahasa yang produktif, sehingga metode yang digunakan sebaiknya adalah metode yang membuat siswa menjadi aktif.

Selain metode pembelajaran bahasa Arab sebagai faktor penting dalam proses belajar mengajar bahasa Arab, ada faktor lain yang mendukung pembelajaran menulis dan menerjemahkan bahasa Arab di MI Al-Jihad Karanggebang. Faktor-faktor tersebut terbagi dalam dua kategori, yaitu faktor intern dan ekstern. Faktor intern yaitu faktor yang berasal dari diri pembelajar, sedangkan faktor ekstern yaitu faktor yang berasal dari luar pembelajaran (Nurul Hidayati, 2019).

Faktor intern meliputi minat dan motivasi dari siswa sedangkan faktor ekstern misalnya tuntutan dari Guru mata pelajaran bahasa Arab. Mayoritas siswa Ml Al-Jihad Karanggebang kurang menyukai pelajaran Bahasa Arab dan ingin menguasainya. Padahal keinginan yang besar siswa untuk menguasai Bahasa Arab adalah hal yang paling penting yang bisa membantu proses pembelajaran. Hal ini membutuhkan adanya faktor intern berupa motivasi dari dalam diri siswa untuk menguasi bahasa Arab dan faktor ekstern berupa tuntutan dari Guru Bahasa Arab.

Selain dari faktor di atas, ada pula kegiatan ekstra Pengembangan Bahasa Asing di Madrasah Ibtidaiyah Al Jihad Karanggebang Jetis Ponorogo ini, yakni pengembangan Bahasa Inggris dan pengembangan Bahasa Arab yang dilaksanakan setiap hari Selasa 


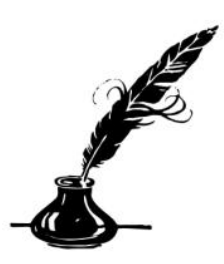

APHORISME

Journal of Arabic Language, Literature, and Education

Vol. 1, No.1(2020)

Aphorisme@insuriponorogo.ac.id

Homepage:https://ejournal.insuriponorogo.ac.id/index.php/Aphorisme

sampai dengan hari Kamis. Kegiatan tersebut dilaksanakan pada pagi hari sebelum masuk proses belajar mengajar di kelas yaitu pukul 06.30 sampai 07.00 WIB atau 30 menit sebelum masuk kelas. Kegiatan ini tentunya juga termasuk faktor yang sangat mendukung dalam pembelajaran menulis dan menerjemahkan Bahasa Arab siswa di MI Al-Jihad Karanggebang ini (Nurul Hidayati, 2019). Siswa mulai kelas I sampai kelas VI dikenalkan dengan mufradat-mufradat baru yang telah disusun oleh para guru menjadi sebuah buku, pada kegiatan tersebut salah satu siswa membacakan dan siswa yang lain menirukan mufradat tersebut. Selain menghafal mufradat, siswa juga menghafal Mahfudhot dan hadis-hadis Nabi. Dengan pembiasaan menirukan mufradat-mufradat itu maka siswa lambat laun mulai mengenal mufradat dan tanpa disadari telah menghafalnya karena terbiasa mengucapkan mufradat-mufradat dalam kegiatan pengembangan bahasa.

PROBLEMATIKA PEMBELAJARAN KITĀBAH DAN TARJAMAH DI MI AL-JIHAD KARANGGEBANG JETIS PONOROGO

Orang Indonesia yang ingin mempelajari bahasa Arab sebagai bahasa asing pasti menghadapi problematika, baik masalah linguistik (terkait dengan tata bunyi, kosakata, kalimat dan tulisan) maupun nonlinguistik (yang berkaitan dengan sosio-budaya dan kultural-budaya) (Akrom Malibary, 1976). Demikian juga dalam proses belajar mengajar bahasa Arab di Madrasah Ibtidaiyah Al Jihad Karanggebang Jetis Ponorogo terdapat problematika yang dihadapi baik oleh siswa maupun guru. Sebagaimana data yang peneliti paparkan sebelumnya bahwa ada beberapa problem dalam pembelajaran bahasa Arab terutama pada ketrampilan menulis dan menerjemah bahasa Arab (Nurul Hidayati, 2019).

Problem linguistik dalam pembelajaran bahasa Arab di antaranya adalah kesulitan siswa dalam menulis karena dianggap sangat berbeda dengan tulisan latin, selain bentuk juga perbedaan sederhana penulisan Arab dari kanan ke kiri sedangkan latin dimulai dari kiri ke kanan, tulisan Arab tidak mengenal huruf kapital. Selain hal tersebut tulisan Arab sangat memperhatikan kesesuaian aspek i'rab nya (Ulin Nuha, 2012).

Beberapa siswa beranggapan bahwa bahasa Arab merupakan bahasa yang sulit untuk dipelajari. Berbeda dengan bahasa Indonesia, bahasa Arab mengenal sistem 


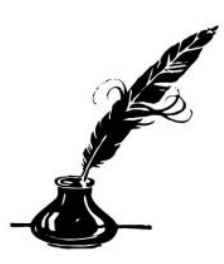

APHORISME

Journal of Arabic Language, Literature, and Education

Vol. 1, No.1(2020)

Aphorisme@insuriponorogo.ac.id

Homepage:https://ejournal.insuriponorogo.ac.id/index.php/Aphorisme

muannats-mudzakkar, kata lampau-sekarang (fi'il madhi-mudhori'). Hal ini yang membuat siswa merasa kesulitan untuk mempelajari bahasa Arab. Selain itu, siswa kurang rajin mempelajari bahasa Arab. Karena belajar bahasa asing khususnya bahasa Arab membutuhkan waktu yang tidak singkat, maka dibutuhkan ketekunan dalam mempelajarinya. Jika siswa malas untuk mempelajarinya, maka pendengaran mereka asing dengan mufradat-mufradat bahasa Arab sehingga akan menemui kesulitan dalam menulis dan menerjemahkan bahasa Arab.

Siswa MI Al-Jihad terbiasa dengan menulis tegak bersambung dibanding menulis huruf hijaiyah. Kebiasaan ini membuat siswa kurang terlatih menulis huruf hijaiyah. Selain itu siswa juga enggan menerapkan program pengembangan bahasa dalam lingkungan sekolah, misalnya dalam aktifitas di luar kelas seperti ketika meminjam buku di perpustakaan, siswa dianjurkan untuk menggunakan bahasa Arab. Mereka diharapkan terbiasa dengan kosa kata bahasa Arab dan memahami makna serta penggunaannya. Namun hal tersebut menjadi problem nonlinguistik siswa, yaitu kurangnya kesadaran siswa untuk membiasakan mempraktikkan bahasa Arab itu sendiri (Nurul Hidayati, 2019).

Dalam menulis dan menerjemahkan bahasa Arab dibutuhkan pengetahuan tentang huruf hijaiyah, sedangkan sebagian siswa kelas V MI Al-Jihad Karanggebang berada pada level Iqra', sehingga mereka menemui kesulitan untuk merangkai huruf hijaiyah dalam pembelajaran menulis dan menerjemahkan bahasa Arab di kelasnya. Dari fenomena tersebut tidak mengherankan karena para pelajar di Indonesia sampai tingkat perguruan tinggi, masih tetap sering melakukan kesalahan-kesalahan dalam menulis dan menerjemah bahasa Arab. Hal ini terjadi karena seakan-akan kesalahan dalam menulis dan menerjemah bahasa Arab sudah menjadi kebiasaan dan adat yang dimulai sejak ibtidaiyah (Zulhannan, 2014). Maka untuk memutus rantai kesalahan tersebut, perlu perhatian lebih dari para pengajar bahasa Arab di tingkatan Madrasah Ibtidaiyah. Penguasaan keterampilan kitabah dan tarjamah sangat penting guna mendukung siswa belajar bahasa arab pada jenjang berikutnya, yaitu Madrasah Tsanawiyah dan 'Aliyah hingga Perguruan Tinggi. 




APHORISME

Journal of Arabic Language, Literature, and Education

Vol. 1, No.1(2020)

Aphorisme@insuriponorogo.ac.id

Homepage:https://ejournal.insuriponorogo.ac.id/index.php/Aphorisme

UPAYA GURU BAHASA ARAB DALAM MENGATASI PROBLEMATIKA PEMBELAJARAN KITĀBAH DAN TARJAMAH DI MI AL-JIHAD KARANGGEBANG JETIS PONOROGO

Sebagai solusi dari problematika pembelajaran Kitābah dan tarjamah di Ml Al Jihad Karanggebang Jetis Ponorogo guru Bahasa Arab Ml Al-Jihad Karanggebang melakukan upaya dalam meningkatkan kemampuan menulis dan menerjemahkan siswa antara lain dengan membiasakan siswa mengenal mufradat bahasa Arab yang digunakan dalam materi pembelajaran. Mufradat-mufradat tersebut dikenalkan dengan metode menjodohkan. Metode ini digunakan dengan media yang bervariasi, sehingga membuat siswa tertarik untuk mempelajari bahasa Arab. Dengan demikian diharapkan siswa dapat menghafal arti dan cara penulisan mufradat-mufradat tersebut, sehingga dapat meningkatkan kemampuan siswa dalam menulis dan menerjemah bahasa Arab (Nurul Hidayati, 2019).

Selain itu siswa juga diterapkan teori behaviouristik. Teori behaviouristik yaitu teori pembiasaan. Siswa dibiasakan dengan mufradat bahasa Arab melalui Program Pengembangan Bahasa Asing. Program ini diharapkan mampu membuat siswa terbiasa dan hafal dengan mufradat-mufradat bahasa Arab. Selain itu, program ini juga menuntut siswa untuk mempraktikkan kemampuan berbahasa Arab secara langsung. Misalnya ketika siswa ingin meminjam buku di perpustakaan, siswa dianjurkan menggunakan kalimat yang sudah diterjemahkan ke dalam bahasa Arab.

Untuk memberikan pemahaman tentang struktur bahasa Arab, Guru bahasa Arab di MI Al-Jihad Karanggebang menggunakan pengantar bahasa Indonesia, baik di dalam kelas maupun saat memberikan tugas (Nurul Hidayati, 2019). Hal ini dimaksudkan agar siswa lebih memahami materi yang disajikan. Selain itu, dalam pembelajaran guru membuka sesi tanya jawab. Siswa dapat bertanya tentang materi yang belum dikuasai, baik itu tentang menulis maupun menerjemahkan bahasa Arab.

\section{KESIMPULAN}

Pembelajaran Bahasa Arab di MI Al-Jihad Karanggebang berdasarkan input ada berakibat pada keterbatasan guru dalam memformulasi pembelajaran yang ideal, sehingga dalam kegiatan belajar mengajar Bahasa Arab di Ml tersebut menggunakan metode ceramah dan dikte untuk ketrampilan menulis dan menerjemah. Metode tersebut dirasa belum 




APHORISME

Journal of Arabic Language, Literature, and Education

Vol. 1, No. 1(2020)

Aphorisme@insuriponorogo.ac.id

Homepage:https://ejournal.insuriponorogo.ac.id/index.php/Aphorisme

dapat meningkatkan motivasi siswa untuk lebih aktif dalam pembelajaran bahasa Arab. Siswa masih tetap beranggapan bahwa bahasa Arab adalah sebuah pelajaran yang menjadi momok bagi para siswa, hal tersebut membutuhkan kreativitas guru yang lebih dalam mendesain pembelajaran bahasa Arab khususnya dalam ketrampilan menulis dan menerjemah sehingga dapat menarik dan menambah motivasi siswa untuk terus mengembangkan diri dalam pembelajaran bahasa Arab.

\section{BIBLIOGRAFI}

Fuad Effendy, Ahmad. (2009). Metodologi Pengajaran Bahasa Arab, Jombang: MISYKAT. Hermawan, Acep, ( 2011). Metodologi Pembelajaran Bahasa Arab, Bandung : PT. Remaja Rosdakarya.

Jos D Parera, (1997). Linguistik Edukasional, Jakarta: Erlangga.

M. Zaka, Al Farisi. (2011). Pedoman Menerjemah Arab Indonesia, Bandung: PT. Remaja Rosdakarya.

Makmun, Abin Syamsuddin. (2005). Psikologi Pendidikan. Bandung: PT. Remaja Rosda Karya.

Malibary, A Akrom dkk, (1976). Pedoman pengajaran Bahasa Arab pada Perguruan Tinggi/IAIN, Jakarta: Depag R.I.

Muhaimin dkk. (1996). Strategi Belajar Mengajar, Surabaya: CV. Citra Media.

Rusyana, Yus. (1988). Bahasa dan sastra dalam Gamitan Pendidikan, Bandung: Diponegoro.

Sugiyono. (2008). Metode Penelitian Kuantitatif, Kualitatif, dan R\&D, Bandung Alfabeta. Ulin Nuha. (2012). Metodologi Super Efektif Pembelajaran Bahasa Arab, Jogjakarta: Diva Press. 